\title{
Occupy and the Temporal Politics of Prefigurative Democracy
}

\author{
Kamilla Petrick
}

\author{
Postdoctoral Research Fellow, Lakehead University Orillia, Canada, \\ kpetrick@lakeheadu.ca
}

\begin{abstract}
This article sheds new light on the Occupy movement by foregrounding its temporal dimensions, particularly in relation to a previous major cycle of transnational contention, the alter-globalization movement (AGM). The discussion engages three temporal considerations in particular: 1) the centrality of instantaneous digital media to both movements' rapid rise and diffusion 2) the pervasiveness - especially within Occupy - of the temporal ethos of prefigurative politics, and 3) the sustainability and longer-term legacy of the Occupy cycle, from the temporal vantage point of the year 2016, i.e. five years since the movement's rise and prompt demise, and fifteen years since the peak of the AGM. The article's conclusion insists on the importance of a long-term vision when it comes to evaluating the outcomes of collective action.
\end{abstract}

Keywords: Occupy movement, Alter-globalization movement, Time, Temporality, Capitalism, Prefigurative politics, Strategy

On October 15, 2011, about three weeks after a group of activists began to camp in Zuccotti Park in lower Manhattan, thousands of people around the world responded to a global "call to action," and in a massive display of solidarity and shared antistatus quo sentiment, began to Occupy public spaces in 951 cities in 82 countries, including St. James park in downtown Toronto, Canada. ${ }^{1}$

Later that month, in a column published on the alternative news website Rabble.ca, Canadian journalist, activist, and author of No Logo (2000), Naomi Klein waxed enthusiastic about the future prospects of the transnational Occupy movement. She commended the protesters for learning from the mistakes of the so-called "anti-globalization" movement, as evidenced, first of all, by Occupy's commitment to non-violence, and second, by the protesters' choice of sustained physical presence as their "fixed target" (Klein 2011). Since the anti-globalization movement was oriented primarily to organizing ephemeral protests against international summits, Klein argued, it would "regularly appear, grab world headlines, then disappear," making it easier for the movement to "fall apart" after 9-11. By contrast, the Occupy Wall Street movement had "time to put down roots, which makes it a lot harder to sweep them away, even if they get kicked out of one physical space" (Ibid.).

Naomi Klein was certainly right to assert the "counter-temporality" of Occupy's defining tactic of open-ended duration, in contrast to the event-driven, "one-off" mode of engagement typified by the "counter-summit" protests of the anti-or, better yet, alter-globalization movement (AGM). Yet a couple of months after her optimistic

\footnotetext{
${ }^{1}$ Though the original source of these figures remains unclear and conflicting figures can be found, the numbers cited above have been widely accepted by both mainstream and activist media as "the standard definition of the scale of the Occupy protests," according to The Guardian ("Occupy Protests").
} 
assessment, the Occupy encampments were dismantled in a wave of evictions that swept the globe in late fall and early winter 2011-2012. Having lost physical ground, the movement also lost the mainstream media spotlight, and then much of its momentum. As public interest and support began to wane, the Occupy assemblies relocated to other spaces, where activists sought to regroup and reconfigure their movement without a permanent physical presence. What can and has been said to remain of Occupy today? In what ways, if any, did it manage to transcend the tendency of the alter-globalization movement toward short-term and largely ephemeral forms of mobilization? What role did the temporal outlook inherent in prefigurative politics play in influencing the movement's strategic orientation? The temporal analytical lens espoused in this article allows us to examine these questions in order to reveal significant yet under-studied temporal dimensions of the Occupy movement, particularly as compared to one of its major transnational precursors, the alter-globalization movement.

The ensuing discussion focuses specifically on the following set of temporal considerations: 1) the centrality of instantaneous digital media to both movements' rapid rise and diffusion 2) the pervasiveness - especially within Occupy - of the temporal ethos of prefigurative politics, and 3) the sustainability and longer term legacy of the Occupy cycle, from the temporal vantage point of the year 2016, i.e. five years since the movement's rise and prompt demise, and fifteen years since the peak of the AGM.

The research approach adopted in this article is qualitative, involving analysis of secondary as well as primary sources, including activist blogs and other movement writings, combined with my first-hand observations inside Occupy Toronto (OT) and (both recorded and unrecorded) informal conversations with core OT organizers, carried out on-site in 2011 and later in 2013. Using this multiplicity of sources, my aim is to render explicit some of the rarely acknowledged temporal dynamics that influenced the trajectory and outcomes of the Occupy movement, and continue to shape the logic and tendencies of collective contentious action today.

\section{New Media Activism and the Speed of Diffusion}

To begin, it may be useful to offer a cursory overview of the AGM, the older of the two transnational "cycles of contention" considered here (see Tarrow 1998). Like Occupy, the AGM was largely driven by opposition to corporate greed and often to capitalism itself; however, the Occupy movement seems to have focused more on exposing the corrosive influence of wealth on the political process, as made manifest by Occupy Wall Street's attempts to pass state and local resolutions to overturn Citizens United and draft a constitutional amendment declaring that corporations are not people and money is not speech (Levitin 2015). For its part, the AGM tended to concentrate mostly on combating free trade, sweatshops, and consumerism; in so doing, its constituents often sought to engage with formal state politics, arguably more so than the Occupy movement ever did (the aforementioned resistance to Citizens United notwithstanding) in targeting formal political institutions such as the World Trade Organization, the World Bank, the International Monetary Fund, plus various multilateral trade agreements among national governments. Commonly considered to have emerged in the mid- to late 1990s - most spectacularly as protests in the streets of Seattle in 1999 against the World Trade Organization - the AGM adopted as its main tactic the organizing of "counter-summit" protests in opposition to the meetings and policies of these global governance institutions. Having peaked at the turn of the millennium, with massive, multiple Global Days of Action transpiring in 
cities around the world, the AGM subsequently declined in many ways and places in the repressive political climate created post-9/11. Briefly if spectacularly resurgent in 2003 in the form of mass protests against the ensuing US invasion of Iraq, the AGM proceeded from there in distinct ways depending on domestic political opportunities (see della Porta 2007); however, as of the mid-2000s, the AGM may be said to have largely waned as a wave of protest.

That is not to say that the AGM's influence has been lost in the dustbin of history. Although the reliance on short-term organizing networks did not endow the movement with the sort of durable infrastructure required to survive amidst a crackdown on dissent, elements of the AGM's tactical approach and legacy could be clearly seen in the principles animating an ensuing transnational cycle of protest to rise and circulate rapidly around the globe, the Occupy movement. A temporal lens can help us to illuminate the relevant continuities and tendencies, shedding new light on patterns and biases of contemporary activism more broadly.

First, a key way in which the AGM paved the path for Occupy was by pioneering the use of digital media for activist purposes. Starting in the mid-1990s, as digital technologies began to proliferate in social life, the nascent AGM became the first social movement cycle to have the internet and related tools at its disposal. The role of the internet in the uprising of the Zapatistas, the campaign against the Multilateral Agreement on Investment, and the creation of Indymedia, the world's first grassroots, internet-based, alternative news network that spread to 150 sites across six continents (see Cleaver 1995; Ayers 1998; Pickard 2006; Wolfson 2014), has been widely celebrated in scholarly accounts as proof of the emancipatory power of "new media activism." According to these optimistic accounts (Castells 1996; Meikle 2002; DyerWitheford 1999), the internet permitted the AGM's highly heterogeneous actors to come together in fluid, decentralized, horizontal networks to "rhizomatically" target shared political targets. Influenced by a confluence of postmodern and anarchist, anti-authoritarian sensibilities, much of the AGM eschewed the perceived hierarchies of the Old Left as well as those of the state and the capitalist system (Wolfson 2014, 187), and the new digital technologies of communication at its disposal both mirrored and amplified this political orientation.

As in the case of the AGM, new media were central to the rapid rise and spread of Occupy. In addition to email and the World Wide Web, Occupy protesters were further able to marshal novel media platforms and technologies, notably social media, Livestreaming and related platforms like InterOccupynet, Globalrevolution.tv, and NYCGA.cc. (Constanza-Chock 2012). The initial callout to Occupy Wall Street was likewise issued online, by the Vancouver-based alternative magazine Adbusters, which had played a key role in shaping the anti-consumerist orientation of the AGM (in tandem with Naomi Klein's No Logo), and had over the years managed to build up and maintain a network of thousands of supporters, expanding its activities to the social media realm.

In mid-2011, Adbusters issued on social media the spark that would ignite the Occupy movement: a poster showing a ballerina poised atop a bull sculpture near Wall Street in Manhattan, captioned with the Twitter hashtag \#OCCUPYWALLSTREET. The hashtag also accompanied a Tweet in which Adbusters called on people to "flood into lower Manhattan, set up tents, kitchens, peaceful barricades and occupy Wall Street" on September 17 - a call to action subsequently endorsed by Anonymous (Constanza-Chock 2012, 2). Digital media were thus central to mobilizing the initial group of several hundred protesters, many of whom decided to stay put and set up camp in Zuccotti Park (formerly known as Liberty Plaza Park), a few blocks north 
of Wall Street. Not insignificantly from our temporal perspective, Zuccotti Park was the only public park in the area open 24/7, due to its curious New York designation as a "privately owned public space" (Gitlin 2012, 19).

Yet despite the activists' ongoing online activity, the occupation in Zuccotti park initially attracted little mainstream media attention. Without reducing the movement's origins to the power of technology, one important factor that did help to propel Occupy Wall Street into global popular consciousness was the rapid online proliferation of amateur videos showing police brutality against the protesters camping out in Zuccotti Park. Having gone viral, the videos were soon afterwards noticed and broadcast by mainstream media. A similar situation occurred on October $1^{\text {st }}$, during the OWS march across the Brooklyn Bridge that resulted in hundreds of arrests and ended up generating a lot of broadcast, print, and social media attention (Constanza-Chock 2012).

The central role played by digital and social media in the emergence and organizing of the AGM and Occupy (see Kavada 2015; Juris 2012; Castells 2012; for a critical perspective see Fuchs 2014) attests to their shared status as movements constitutive of a mode of political engagement commonly considered in communication studies literature as "new media activism," or alternatively, the "cyber left" (Wolfson 2014). Central to this mode of activism is the ease and perhaps most importantly, the speed of communication that allows both internal coordination and external outreach to transpire rapidly across transnational borders. But for all its strengths and advantages, this mode of activism is not without problems.

\section{Fast Capitalism In and Out of Crisis}

From a critical temporal perspective, it is important to acknowledge that the speed of communication flows facilitated by global media is also and primarily, a boon to neoliberal capitalism. As recognized by a growing literature of "time studies," the speed imperative constitutes a core dynamic of the capitalist system, predicated on competition and the need to commodify labour time and accelerate the turnover time of capital by speeding up research and development, production, distribution, and consumption cycles (see Harvey 1989, Hassan 2003, 2009; Manzerolle and Kjøsen 2012).

Though some of them in particular are not immune to class-based critique, oppositional cultural movements, such as the slow cities or the slow food movement, have emerged in order to challenge consumer society's hegemonic "culture of speed" (Tomlinson 2007), along with popular works bearing titles like In Praise of Slowness (Honoré 2004), which recommend mindfulness and digital detoxes as ways to cope with contemporary time pressures. French farmer José Bové's protest of the agricultural policies of McDonald's restaurants likewise formed part of one of the AGM's main fronts of resistance, specifically to fast profits being made in the agricultural sector by short-sighted and unaccountable multinational corporations.

Another effort at slowing down the speed of capitalism undertaken by elements within both AGM and Occupy involved a concerted push for a financial transactions tax. During the AGM cycle, this endeavour was organized as the campaign for the Tobin tax, named after the economist James Tobin who first proposed a small (up to $0.5 \%)$ FTT in the belief that its implementation would facilitate a slow-down of the pace of finance capital, making the system less sensitive to daily political news and the anticipation of economic policy changes (Patomäki 2000). The campaign involved a coalition of NGOs but was led mainly by the French NGO Association pour la taxation des transactions financières et pour l'action citoyenne (the Association for the 
Taxation of Financial Transactions and for Citizens' Action), or ATTAC. While this campaign subsequently waned in tandem with the AGM cycle, a group of British NGOs revived the demand in 2010, re-branding it as the "Robin Hood Tax." In the fall of 2011, the rebranded campaign got a major boost when Adbusters asked the Occupy General Assemblies, somewhat controversially, to unite behind the demand for the Robin Hood Tax as its "one demand," and to mobilize for a Global Day of Action on the RHT ahead of the 2011 G20 leaders' summit in France (see Elliott 2011). Apart from the new sexy name, the objective of the Robin Hood Tax, embraced by the minority within Occupy interested in engaging with formal politics, remained essentially the same: to curb reckless financial speculation by targeting transactions involving stocks, bonds, foreign exchange, and derivatives, whose short-term, casino-style trading was commonly identified by Occupy activists as responsible for the 2008 economic crisis.

To elaborate, the systemic volatility of capitalism has been exacerbated significantly since the 1970s, with the rise of the nexus between global information and communication technologies (ICTs) and neoliberal globalization. The resulting postFordist "regime of flexible accumulation" (Harvey 1989) has put in place informational facilities for around-the-clock financial trading, now increasingly executed at hyperspeeds with the aid of complex algorithms. The widespread turn to high-frequency trading (HFT) has all but removed from the equation the unprofitably slow human trader. Near-instantaneous financial flows enabled by new technologies have exacerbated the built-in tendency toward crisis of a mode of accumulation that various scholars have conceptualized as fast, turbo, or casino capitalism (Agger 2004; Luttwak 1999; Strange 1986).

To be sure, "fast capitalism" does not constitute a fundamental break with Fordism or capitalism itself; it is but the latest phase of the financialization of the capital accumulation process that makes trading in "fictitious capital" assets, such as stocks, bonds, and derivatives, particularly lucrative, as demonstrated by the growth of financial profits as a percent of total profits (see Bellamy Foster 2008). Buffered by the American state, finance capital has played a central role in the making of global capitalism, and was pivotal in the creation of the giant bubble inside the US housing sector. Like the 1920s bubble that ushered in the Great Depression, the few years before the 2009 crisis were marked by feverish financial speculation that inflated real estate prices and stocks and ended in financial meltdown (Panitch, Gindin and Albo 2010). Capitalism's tendency crisis was recognized over a century ago by Karl Marx, who predicted that the system would bring about its own ruin by eventually destroying its supporting social structures. The last four decades of neoliberal restructuring have achieved just that, effectively impoverishing the working classes by making employment fast and flexible, outsourcing jobs, and gutting state services. Personal debt ballooned as debt markets rapidly expanded, further boosting the process of financialization. This processes likewise transpired within the American housing market, but when the debt markets hit their inevitable expansion limit and no new borrowers could be found, the bubble burst and a mega crisis ensued, with devastating results for millions of people. Marked by rising unemployment, record home foreclosures, and ever-higher personal debt, the period between 2008 and 2011 saw the conditions ripen for a major popular uprising.

\section{Prefiguration and the Pace of Decision Making}

In addition to calling for more state regulation of finance, as some elements within the Occupy movement have done, the Occupy cycle was also a show of resistance to 
capitalism's speed imperative through its emphasis on slow and prefigurative living and decision-making. In fact, both the alter-globalization movement and the Occupy movement can be said to have been shaped by the specific temporality implicit in prefigurative politics. The prefigurative ethos stresses the importance of the process by which the decisions are made collectively, rather than or in addition to the outcomes of such deliberations. In contradistinction to the orthodox socialist telos that sees revolution as a future event, prefigurative politics seeks to enact desired social changes in the present moment.

This prefigurative ethos at the heart of the Occupy movement was summarized aptly by an editorial in the progressive alternative Canadian magazine Briarpatch, in their article "Reimagining Revolution":

In addition to bringing income inequality to the forefront of political discourse, the movement has demonstrated new ways (or ancient ways, reimagined) of organizing and taking care of one another. Through strategies such as consensus-based general assemblies, the human microphone, gift economies and volunteer committees to feed, clothe, inform and entertain one another, the movements have begun to model a sustainable, non-hierarchical alternative to the capitalist system (Briarpatch 2012).

In other words, the internal functioning of the Occupations was meant to prefigure the kind of future society desired by the activists - building a new society in the shell of the old, as the saying goes. It is an ethos associated with anarchism and its tradition of mutual aid as well as with feminism and its notion that "the revolution begins at home," and that alternative life and reproductive practices produce desirable alternative social relations (see Federici in Haiven 2011; Conway 2013, 149).

Within the AGM, the World Social Forum seems to offer the closest equivalent to Occupations as a site of prefigurative politics. The WSF continues to take place as an annual conference of activists from various social movements around the world. Its "knowledge ethos" as analyzed by Janet Conway closely resembles that prioritized by Occupy insofar as it is centred on "practices, process, prefiguration, and the longue durée over theory, content, instrumental reason, and immediacy" (Conway 2013, 148). As noted further by Conway, the "central insight of the WSF rests in creating an open space and initiating an open-ended process, not in producing an authoritative body of content, nor in creating a political instrument with a fixed strategy and programme which is oriented to pre-established outcomes" (Ibid.).

At the same time, the Occupy movement took place in public spaces in hundreds of urban settings, meaning that locals could easily join the encampments with little resources at their disposal. For its part, the WSF faced criticism that it was exclusionary to the extent that it requires access to resources (and associated class privilege) to be able to attend the event as an international participant; hence participation has tended to be limited to Westerners and/or urban-based professionals or students organized through NGOs, the internet, and their knowledge of colonial languages (lbid., 156-57). To redress this issue and rebuke what was seen as elitism of the WSF organizing committees, the Inter-Continental Youth Camp was created in 2011 as an affordable camping site for young WSF delegates. Representing a closer equivalent to Occupy than the WSF in this respect, the Youth Camp, associated by Conway with AGM's autonomist currents, was focused on enacting direct or what I 
am calling here prefigurative democracy, by virtue of operating as a "laboratory of practices" and "collective experimentation in horizontalism, self-management, and ecologically sustainable practices" (Ibid.).

From the temporal perspective, however, a further difference between Occupy and WSF/ICY may be observed, in that the latter were and remain short-lived events that are not structurally designed to conduce to long-term coalition work. In large measure for this reason, a decade following the AGM's peak and the first WSF, the excitement on the Left about a new cycle of protest on the rise called Occupy Wall Street derived in large part from the uniqueness and the gravitas of its open-ended temporality: to Occupy was no limited-term commitment.

The prefigurative focus was also manifest in the strategic organizing priorities of the various Occupations, and I would like to suggest, somewhat problematically so. At least in Toronto, the focus of the twice-daily General Assemblies revolved heavily around logistics and the internal operations of the camps. Maintaining the camp was time-consuming and immediate. In this fashion, it became an end in itself, as noted by a core OT organizer, whose socialist politics rendered her somewhat critical of this tendency as she noted that "a lot of people were just there to be there, they weren't in an activist frame of mind, and a lot of them were contributing to food tent or logistics but in terms of actually organizing there weren't that many people involved." This critique of the Occupy movement, which another anarchist activist I spoke with encapsulated with a characterization of the OT encampment as "a glorified anarchist soup kitchen," echoes that made by OWS participant Smucker (2014), who noted the presence of two tendencies within Occupy Wall Street: the "strategic politics" tendency that he sees a subordinate to the competing tendency he called the "prefigurative politics tendency" and characterized as "the most visible," and "fixated on its own decision-making process."

This latter preoccupation within both the AGM and the Occupy could clearly be seen in activists' commitment to collective decision-making on the basis of the consensus model. Within AGM, this model was espoused by ad-hoc decision-making convergences known as "spokescouncils," which comprised representatives of "affinity groups," in turn made up of a handful of people interested in organizing together and attending protests as an ensemble for the sake of mutual safety. In the consensus model, full agreement from everyone present at the meeting is required, and every person has the power to "block" (i.e. veto) a decision that they find utterly unacceptable - for this reason, the consensus model is widely supported among anarchists and anti-authoritarians, who see it as "the only form of decision-making that could operate without coercive enforcement - since if a majority does not have the means to compel a minority to obey its dictates, all decisions will, of necessity, have to be made by general consent" (Graeber 2011, n.p.).

Over a decade following the height of the AGM, the "spokescouncil" model proved equally if not more significant to the functioning of the Occupy movement. Given a new name ("the General Assembly"), the model remained influenced by anarchist principles of horizontalism and direct democracy, and it brought Occupiers together at least once daily in large and open camp gatherings where to make decisions.

There are solid advantages to using consensus decision-making. In the words of one OWS activist, "When they [Occupiers] finally get to consensus on some issue, often after days and days of trying, the feeling is quite incredible. A mighty cheer fills the plaza" (quoted in Schneider 2011). The main disadvantage of consensusbuilding is temporal: a lot of time is typically required to achieve full agreement during a General Assembly. In a section called "Time" found in an online consensus- 
model manual, the author deploys the terminology of the AGM in noting that "[a]II decision making techniques are going to need time if the quality of the decision is going to be good. Consensus is no different - it needs enough time both for making decisions and for learning to work by consensus. In spokes councils you need to allow time for affinity groups to consult and come to their own consensus" (Consensus in Large Groups"). The availability of time thus emerges as a key ingredient in attempts at truly democratic decision making (see Rosa 2005). As one OWS activist put it bluntly: consensus building is "really hard, frustrating and slow" (quoted in Schneider 2011).

Considering the conditions of life in late capitalist, high-speed society where time pressures are experienced more acutely than before (see Rosa 2013; Scheuerman 2009; Hassan 2009), the length of time usually required to reach full consensus often carries unintended, exclusionary consequences. Often, it is only those with relatively fewer external commitments (e.g. caretaking, employment) who are in the position to continue their participation in long discussion. Therefore, although it is prefiguratively democratic in the sense of being inclusive and participatory, the inefficiency of $100 \%$ consensus decision-making typical of AGM and Occupy alike (in contrast to modified consensus requiring less than $100 \%$ agreement among all) means that it is also not necessarily nor optimally democratic.

This problem came to a head inside Occupy Toronto in the wake of its eviction from St. James park in November of 2011. Through December 2011 and the first weeks of 2012, a group of activists continued to meet daily in General Assemblies held in a city square, braving the brutal cold of Canadian winter. Exemplifying the shortcomings of consensus, it took almost the entire winter before activists reached consensus to move the General Assembly process indoors. Anecdotal evidence combined with social media posts by Occupy Toronto at the time revealed that when spring finally arrived, Occupy Toronto had split internally into two camps, including the so-called "Cloud Gardens General Assembly," whose first move was to shift to a supermajority model requiring 90 rather than 100 percent consensus. From the temporal perspective espoused in this article, it is significant that (as recorded in the minutes from its March 8, 2012 General Assembly, posted online) this decision was made because " $90 \%$ consensus is more representational than $100 \%$, as $100 \%$ represents the people who have the patience to have slow discussions" (GA minutes"; emphasis added). To "patience," we may wish to add "capacity," given that involuntary life obligations are equally if not more significant factors when it comes to one's ability to participate fully in lengthy consensus-building processes.

Yet, even when decisions are made by a supermajority rather than 100 percent consensus, other temporal pressures can and have emerged to challenge and undermine the prefiguratively democratic functioning of Occupy. Like the broader movement, Occupy Toronto was committed to operating in a leaderless, horizontal manner; however, as feminist activist Jo Freeman recognized in the early 1970s, even the most resolutely anti-authoritarian movements are prone to what she called "the tyranny of structurelessness," involving the emergence of informal and thus often unaccountable leaders (see Freeman n.d.)

As with the AGM and other movements before it, this also proved to be the case in Occupy Toronto, as a group of several young leaders gradually emerged within Occupy Toronto and assumed an informal leadership role. While their status in St. James park was without a doubt rooted in their hard work and dedication, it was also based in part on a temporal hierarchy of sorts, determined by their length of stay in the camp. While this may be said to apply to activists fighting for any cause, the ca- 
chet associated with sustained presence as Occupy's defining tactic meant that there was an extra degree of credibility and influence to be derived from being a full-time Occupier. Based on my first-hand observation and participation in the OT's General Assemblies, it was commonplace for the long-term Occupiers to preface their comments by stating their name and the number of days they had been staying in the park - all in one breath.

Though they were widely recognised by fellow protesters as the "go-to" people, their movement's commitment to horizontality and prefigurative democracy meant that the informal leaders of Occupy Toronto possessed no formal authority to make executive decisions independently of the General Assembly, even in times of perceived urgency. This situation sparked a controversy in the camp when an eviction notice was served to Occupy Toronto on November 15, 2011. Reacting to this new and urgent development, the group of informal leaders within Occupy Toronto took it upon themselves to make a fast executive decision, and moved to file an emergency injunction against the eviction notice. They announced this move after the fact, at the General Assembly that same evening, adding that in order to appease the judge appointed to make a ruling on the case, they had also decided to disallow any new tents or Occupiers. The emergency support rally already in motion for that night was also cancelled. Although one of the decision-makers explained at the time that the injunction would buy Occupy Toronto extra time to prepare and decide what to do ("Protesters"), many Occupiers were less than impressed, and many voices argued during that night's General Assembly that decisions regarding the eviction notice should have been made collectively.

The same disgruntlement appears to have emerged in other Occupations; protesters in NYC were, for example, reportedly likewise frustrated - in the words of one observer, "as with every ostensibly leaderless movement, there seem to be things happening behind the scenes" (quoted in Roberts 2012, 757). From the temporal perspective of this paper, it becomes clear that even in a modified form, the slow and prefiguratively democratic model of the GA was clearly limited and hampered by the imperatives of speed and efficiency, including the need for immediate responses when under threat.

There is one more temporal dimension to this that is worth mentioning, insofar as the frequency of the General Assemblies made it difficult for some outside supporters to participate meaningfully in the Occupations when the constraints of the capitalist wage economy meant they could only do so only on a limited, part-time basis. In this light, it is possible to recognize the vitality of the availability of the intangible resource of time, to use the language of social movement studies, which the Occupiers possessed differentially, and often in inverse relationship to their employment security. Those who were full-time Occupiers were not infrequently under- or unemployed, sometimes homeless, often on account of the very austerity policies that became a target of the Occupy movement. As expressed by a poster captured in a widely circulated image, Occupy protesters had "lost a job, found an Occupation."

\section{Durability}

The final temporal dimension to be considered in this article pertains to movement sustainability, or durability. When the Occupy Wall Street movement began in New York City, few thought that the encampment would last very long. Some protesters reportedly thought that it would "fizzle out in a couple of days" (see Schwartz 2011). But it did not, not that quickly anyway. In early October, the movement cycle was only beginning to take off, but already there were reasons for concern concerning its 
staying power. In a speech she gave at Occupy Wall Street on October 6, AGM veteran Naomi Klein pleaded with the protesters to avoid getting trapped in a shorttermist, navel-gazing mentality:

Being horizontal and deeply democratic is wonderful (...) But these principles are compatible with the hard work of building structures and institutions that are sturdy enough to weather the storms ahead...this is not group therapy we also want to change the world. This movement has to create democratic structures. It just can't happen overnight, but I beg you not to fetishize not having a structure. We made that mistake, and it destroyed our movement (quoted in Pinto 2011).

This plea, of course, can be quite challenging to enact in practice, and the case of Occupy Toronto is yet again helpful in illustrating the difficulties. Following their eviction from St. James park in late November, the activists of OT continued their efforts in a reduced capacity for another year or so. According to a core organizer, these activities included a series of "Occupy Talks" on issues ranging from Indigenous perspectives on Occupy to labour and the environment; they also co-organized some events with local activist groups such as the Ontario Coalition Against Poverty and the Toronto chapter of the migrant justice organization No One Is Illegal. However, the organizer recalled, "we no longer had this mini city where we were all living together and communicating on a regular basis. It went down to fewer GAs, and then fewer each week, and so it was no longer the same kind of activism." The Occupy movement's momentum and activist energies were noticeably waning. Hence, following the rally she had helped to organize to mark the first anniversary of OWS, the activist I spoke with recalled being "the last one standing. By that point, most of the other organizers abandoned ship," she added, noting that they were "broke" and had to find jobs. Her comment confirms the aforementioned temporal dimension of Occupy, namely the differential availability of time as a resource of collective action. To reiterate, it was mostly persons possessed of "extra" time (willingly or not) who could dedicate themselves full-time to participation in the Occupy movement. In the context of a high-speed society such as Canada, in which the pervasive sense of "busyness" militates against social actors' perceived ability to engage in democratic life (see Scheuerman 2009), the defining yet highly demanding temporal quality of the Occupy movement limited in substantial ways the individual and collective capacity of Occupy activists to continue to engage in resistance, especially posteviction.

By now it should be clear that the Occupy movement proved too preoccupied with its internal processes to prioritize the formation of political goals or sustained movement infrastructure. Ensuring the survival of the camps became an instrumental end it itself, rather than a means to build a mass base of support among those most deleteriously impacted by corporate greed and global capitalism. As a result, strategic thinking and outreach were for the most part foreshortened, or at best, relegated to the work of smaller sub-committees. The urgency of ensuring Occupy's survival played a key role in shaping this myopic outlook: in the words of a core OT activist who devoted much of her energy to the OT outreach committee, "it would have been helpful to do activism in a setting where we weren't frantically pulling things together on a regular basis... most of the time we were so busy with maintaining this mini city, there was so much work to do to run this space and a lot of problems that came up 
that there wasn't a lot of time for reflection." This "addiction to urgency," as one activist put it in relation to the AGM, had previously informed the AGM's tactical preoccupation with organizing "counter-summits," feeding a tendency on the contemporary activist Left toward a mode of engagement which prioritizes short term, one-off mobilizations, and which I have termed "fast activism" on the basis of empirical research on the trajectory and tendencies of the (Canadian) AGM (Pietrzyk 2013). As this article has sought to illuminate, both the AGM and Occupy were largely focused on the present and short-term concerns to the neglect of building lasting social movement infrastructure. Largely though not exclusively for this reason, both found it difficult to survive and rebuild in the aftermath of their respective moments of crisis.

\section{Final Thought: The Long Game of Revolution}

Ultimately, however, it would hypocritically serve a short-termist bias to deny or overlook the lasting impact of both cycles of contention. Both the AGM and Occupy certainly made a difference insofar as they informed, inspired, and mobilized thousands of people to oppose corporate greed and support associated social justice causes. This commonly made argument was further affirmed by an activist of Occupy Toronto during our informal interview in 2013:

The impact that I see is the wide scale education that happened, and I would argue a chunk of the city is way more aware of various issues as a result of that movement. People gaining organizing skills, more people going to rallies, more people connected to the activist world, more people connected over Facebook and seeing all the events that are happening, so I think it gave the activist movement a big push in general.

In addition, a frequently invoked impact credited to the Occupy movement pertains to the popularization of awareness of growing wealth disparity, as captured by the now famous slogan contrasting the "99 percent" and the " 1 percent." The centring of class struggle within popular discourse inside the "belly of the beast" and beyond surely counts as a win for those advocating against capitalism in favour of equality and prosperity for all.

On the other hand, critical voices, including that of Micah White, a former Adbusters editor credited as one of the instigators of OWS, have asserted that merely raising awareness about wealth disparity and the toxic influence of money on democracy does not constitute success - concrete outcomes do. To White's mind, the Occupy movement did not ultimately achieve what he sees as its overarching goal, i.e. removing money from politics. Consequently, he views the movement as a "constructive failure" (White, quoted in Hunter 2016, n.p.). As 2011, "the year of living dangerously" (Žižek 2012), passed, it seemed that the revolutionary moment waned without having effectively changed much.

Nonetheless, it is important to acknowledge and celebrate the variety of commendable and concrete initiatives that did emerge in the name of the Occupy since its decline. "Occupy Sandy" provided grassroots relief for victims of the hurricane; "Occupy Our Homes" network has fought foreclosures as part of a campaign to support workers' resistance to precarious labour conditions, and the "Occupy Debt" network and its Rolling Jubilee campaign have been fundraising in order to buy up 
(thus abolishing) US student loan and other debts on the secondary and tertiary markets, where they are sold for pennies on the dollar (see StrikeDebt.org). As noted on its website, as of May 2016, it has raised over $\$ 700,000$ dollars, with which it has managed to abolish almost $\$ 32$ million of debt (rollingjubilee.org). A version of Occupy erupted and lasted for several months in Hong Kong, led by students demanding democratic input into their society.

Moreover, the Occupy movement can also be said to have inspired a new wave of labour mobilisation, in the US and beyond. As Levitin (2015) argues, "[o]ne of Occupy's largely unrecognized victories is the momentum it built for a higher minimum wage", motivating fast-food workers in New York City to walk off the job in November 2012, and helping to spark a movement for "\$15 and fairness" that has now spread to other US cities as well as other countries, including Canada. The uprisings against Wal-Mart and McDonald's, the Chicago teachers' strike, can all be seen as components of the Occupy-inspired wave of resurgence within the U.S. labour movement.

These are worthy and important initiatives, and they were directly informed and inspired by Occupy, in addition to being composed of many former Occupiers. Thus, even if Occupy did not fully succeed in uniting the 99 percent into a new, stable historic bloc capable of defeating neoliberalism, it is not at all my intention to discredit or diminish this movement or the ensuing initiatives carried out under its banner, for it is undeniable that they are making a difference, and constitute the less visible but no less vital or important organizing links between the Occupy cycle and whatever organizational form is assumed by the next mass mobilization. And so, although we may take issue with the source of these words of wisdom, Thomas Jefferson was right to observe that "the generation which commences a revolution rarely completes it." In this light, as navel-gazing prone as it can be, prefigurative politics is also right to insist that revolution is not an event, but rather a process. Critical reflection upon contemporary revolutionaries' tendencies, as attempted in this paper, might not necessarily speed up this historic process, but it can, one hopes, permit it to grow in power.

\section{References}

Adbusters. 2011. Robin Hood Global March: Adbusters Tactical Briefing \#15, 17 October. Accessed 12 January, 2015. https://www.adbusters.org/action/occupywallstreet/robinhood-global-march/

Agger, Ben. 2004. Speeding up Fast Capitalism: Cultures, Jobs, Families, Schools, Bodies. Boulder, CO: Paradigm Publishers.

Ayers, Jeffery. M. 1998. Defying Conventional Wisdom: Political Movements and Popular Contention against North American Free Trade. Toronto: University of Toronto Press.

Bellamy Foster, John. 2008. The Financialization of Capital and the Crisis. The Monthly Review 9 (11). Accessed Sept 30, 2016. http://monthlyreview.org/2008/04/01/thefinancialization-of-capital-and-the-crisis/

Briarpatch Staff. 2012. Reimagining Revolution. Briarpatch Magazine, January 1. Accessed March 5, 2012. http://briarpatchmagazine.com/articles/view/reimagining-revolution

Castells, Manuel. 1996. The Rise of the Network Society. The Information age: Economy, Society and Culture, Vol. I. Blackwell, Cambridge, MA.

Castells, Manuel. 2012. Networks of Outrage and Hope: Social Movements in the Internet Age. Cambridge: Polity.

CBC News (online staff). 2011. Protesters celebrate Occupy Toronto stalled eviction. CBC News Toronto, 15 November. Accessed 25 March, 2012. 
http://www.cbc.ca/news/canada/toronto/protesters-celebrate-occupy-toronto-stalledeviction-1.980198

Cleaver, Harry. 1995. The Zapatistas and the Electronic Fabric of Struggle. Accessed January 6, 2016. https://la.utexas.edu/users/hcleaver/zaps.html

Consensus in Large Groups (n.d). Seeds for Change. Accessed 11 June, 2015. www.seedsforchange.org.uk/conslarge.pdf

Conway, Janet M. 2013. Edges of Global Justice: The World Social Forum and Its 'Others' New York: Routledge.

Constanza-Chock, Sasha. 2012. Mic Check! Media Cultures and the Occupy Movement. Social movement Studies: Journal of Social, Cultural and Political Protest 11 (3-4): 375385

della Porta, Donatella, ed. 2007. The Global Justice Movement: Cross-national and transnational perspectives. Boulder: Paradigm Publishers.

Dyer-Witheford, Nick. 1999. Cyber-Marx: The Circuits of Struggle. Urbana, IL: The University of Chicago Press.

Elliott, Justin. 2011. The Origins of Occupy Wall Street Explained. Salon.com, October 4. Accessed March 12, 2016. http://www.salon.com/2011/10/04/adbusters occupy wall st/

Freeman, Jo. n.d. The Tyranny of Structurelessness. Accessed March 21, 2012. http://www.jofreeman.com/joreen/tyranny.htm

Fuchs, Christian. 2014. Occupy Media! The Occupy Movement and Social Media in Crisis Capitalism. Winchester: Zero Books.

GA Minutes: March 82012 @ Harvest Moon. Accessed April 18, 2012 http://occupyto.org/committees/general-assembly-ga/docs/ga-minutes-march-8-2012harvest-moon\#more-961

Gitlin, Todd. 2012. Occupy Nation: The Roots, the Spirit, and the Promise of Occupy Wall Street. New York: it Books.

Graeber, David. 2011. Occupy Wall Street's Anarchist Roots. Al Jazeera English, November 30. Accessed December 14, 2015. http://www.aljazeera.com/indepth/opinion/2011/11/2011112872835904508.html

Graeber, David. 2009. Direct Action: An Ethnography. Oakland, CA: AK Press.

Haiven, Max. 2011. Occupy and the Struggle Over Reproduction: An Interview with Silvia Federici. Rabble.ca. Accessed 21 September, 2016. http://rabble.ca/news/2011/12/occupy-and-struggle-over-reproduction-interview-silviafederici

Harvey, David. 1987. Flexible Accumulation Through Urbanization: Reflections on 'PostModernism' in the American City. Antipode 19: 260-286.

Hassan, Robert. 2003. The Chronoscopic Society: Globalization, Time and Knowledge in the Network Economy. New York: Peter Lang.

Hassan, Robert. 2009. Empires of Speed: Time and the Acceleration of Politics and Society. Lieden: Brill.

Honoré, Carl. 2004. In Praise of Slowness: How a Worldwide Movement is Challenging the Cult of Speed. New York: Harper.

Hunter, Jennifer. 2016. The "constructive failure" of Occupy and the future of social activism. The Toronto Star, March 28.

Juris, Jeffrey S. 2012. Reflections on \#Occupy everywhere: Social media, public space, and emerging logics of aggregation. American Ethnologist 39 (2): 259-279. doi:10.1111/j.1548-1425.2012.01362.x

Kavada, Anastasia. 2015. Creating the Collective: Social Media, the Occupy Movement and its Constitution as a Collective Actor. Information, Communication \& Society 18 (8): 872886. doi: 10.1080/1369118X.2015.1043318

Kayden, Jerold S. 2011. Meet me at the plaza. New York Times, October 19. Accessed March 12, 2016. http://www.nytimes.com/2011/10/20/opinion/zuccotti-park-and-theprivate-plaza-problem.html? $\quad r=0$ 
Klein, Naomi. 2011. Occupy Wall Street: Lessons from Anti-globalization Protests. Rabble.ca. Accessed November 27, 2011. http://rabble.ca/columnists/2011/10/occupywall-street-lessons-anti-globalization-protests

Levitin, Michael. 2015. The Triumph of Occupy Wall Street. The Atlantic, June 10. Accessed December 15, 2015. http://www.theatlantic.com/politics/archive/2015/06/the-triumph-ofoccupy-wall-street/395408/

Luttwak, Edward. 1999. Turbo-Capitalism Winner and Losers in the Global Economy. New York: Harper Collins.

Manzerolle, Vincent R. and Atle Mikkola Kjøsen 2012. The Communication of Capital: Digital Media and the Logic of Acceleration. triple C: Communication, Capitalism \& Critique 10 (2): 214-229.

Marx, Karl. 1973. The Grundrisse. Penguin: Harmondsworth.

McNally, David. 2002. Another World Is Possible: Globalization and Anti-capitalism. Winnipeg: Arbeiter.

Meikle, Graham. 2002. Future Active: Media Activism and the Internet. London: Routledge.

Occupy Protests Around the World: full list visualised. 2011. The Guardian, October 17. http://www.guardian.co.uk/news/datablog/2011/oct/17/occupy-protests-world-list-map Accessed January 30, 2012.

Panitch, Leo, Sam Gindin and Greg Albo. 2010. In and Out of Crisis: The Global Financial Crisis and Left Alternatives. Oakland, CA: PM Press.

Patomäki, Heike. 2000. The Tobin Tax: A New Phase in the Politics of Globalization? Theory, Culture and Society 17 (4): 77-91.

Pickard, Victor. 2006. United yet Autonomous: Indymedia and the Struggle to Sustain a Radical Democratic Network. Media, Culture \& Society 28 (3): 315-336.

Pietrzyk, Kamilla. 2013. Time, Technology and Troublemakers: "Fast Activism" and the AlterGlobalization Movement in Canada. PhD Dissertation. York University, Toronto, Canada.

Pinto, Nick. 2011. Naomi Klein to Occupy Wall Street: get organized. Village Voice, October 7. Accessed January 11, 2012. http://blogs.villagevoice.com/runninscared/2011/10/naomi klein to.php.

Reimagining Revolution. 2012. Briarpatch Magazine, January 1. Accessed March 5, 2012. http://briarpatchmagazine.com/articles/view/reimagining-revolution

Roberts, Alasdair. 2012. Why the Occupy Movement Failed. Public Administration Review 72 (5): 754-762.

Rosa, Hartmut. 2005. The Speed of Global Flows and the Pace of Democratic Politics. New Political Science 27 (4): 445-459.

Rosa, Hartmut. 2013. Social Acceleration: A New Theory of Modernity. New York: Columbia University Press.

Scheuerman, William E. 2009. Citizenship and Speed. In High Speed Society: Social Acceleration, Power, and Modernity, edited by Hartmut Rosa and William E. Scheuerman, 287-306. University Park, PA: Pennsylvania State University Press.

Schneider, Nathan. 2011. Occupy Wall Street: FAQ. The Nation, September 29. Accessed January 12, 2013. http://www.thenation.com/article/163719/occupy-wall-street-faq\#

Schwartz, Mattathias. 2011. Pre-Occupied: The Origins and Future of Occupy Wall Street. The New Yorker, November 28. Accessed January 12, 2015. http://www.newyorker.com/magazine/2011/11/28/pre-occupied

Smucker, Jonathan M. 2014. Can Prefigurative Politics Replace Political Strategy? Berkeley Journal of Sociology 58, Accessed October 2, 2016. http://berkeleyjournal.org/2014/10/can-prefigurative-politics-replace-political-strategy/

Strange, Susan. 1986. Casino Capitalism. Oxford: Blackwell.

Tarrow, Sidney. 1998. Power in Movement: Social Movements and Contentious Politics. New York: Cambridge University Press.

Tomlinson, John. 2007. The Culture of Speed: The Coming of Immediacy. London, LA: Sage. 
White, Micah. 2016. The End of Protest: A New Playbook for Revolution. Toronto: Knopf Canada.

Wolfson, Todd. 2014. Digital Rebellion: The Birth of the Cyber Left. Urbana, IL: University of Illinois Press.

Žižek, Slavoj. 2012. The Year of Living Dangerously. New York: Verso.

\section{About the Author}

Kamilla Petrick

Kamilla Petrick is a postdoctoral researcher in the Department of Interdisciplinary Studies at Lakehead University Orillia and a lecturer in Communication Studies at York University (Canada). She holds a doctorate in political science and two prior degrees in media studies. Her research interests include digital culture, social movements, political economy, time and temporality, collective memory, and the role of technology in social transformation. 